\title{
School Desegregation After Swann: A Theory of Government Responsibility
}

Eighteen years ago, Brown v. Board of Education ${ }^{1}$ condemned segregated schools as inherently inferior. After hundreds of desegregation cases, most black children continue to attend segregated schools, ${ }^{2}$ which remain inferior. ${ }^{3}$ Although the reasons for this failure are numerous and complex, ${ }^{4}$ one persistent problem has been the inability of courts to develop consistent standards for determining the constitutionality of a school system in which racial imbalance exists. In April, 1971, in Swann v. Charlotte-Mecklenburg Board of Education, ${ }^{5}$ the Supreme Court finally articulated some guidelines to assist lower courts in making this determination. The Court focused primarily on the remedial devices, including busing and assignment by race, that could appropriately be used to overcome state-imposed segregation. The Court did not, however, provide any significant guidance for determining when segregation should be considered "state-imposed."B Consequently, this question remains enveloped in uncertainty.

1347 U.S. 483 (1954).

2 See 1 U.S. Comm'N ON Civil Rights, Racial Isolation in the Public Schools 2-7 (1967) [hereinafter cited as RACIAL IsOLATION]. Recent statistics indicate increased progress; but as of 1970, approximately fifty percent of black students still attended all- or almost all-black schools. U.S. Dep't of Health, Education \& Welfare, News Release, June 18, 1971.

3 It is clear that the inferiority of black schools cannot be attributed to any one factor. Those factors mentioned most often include (l) underallocation of resources to the minority group school, (2) lack of contact with students from advantaged socioeconomic backgrounds, (3) inferiority of educational environment in the economically deprived family, and (4) stigmatization of the black children resulting from the state-imposed or -sanctioned racial separation. While it is true that some of these educational factors can be overcome without integration, the continued existence of segregated school systems will remain a barrier in the long run to meaningful integration of the races. Moreover, the continued inferiority of black schools is strong evidence that Brown I's initial assumption of inherent inequality was accurate, although it has been subjected to increasing criticism. E.g., Cohen, Defining Racial Equality in Education, 16 U.C.L.A.L. REv. 255, 258 (1969). See generally Racial Isolation, supra note 2, at 73-114; U.S. DEP'T OF HEALTH, Education \&: Welfare, Equality of Educational Opportunity (J. Coleman ed. 1966); Schoettle, The Equal Protection Clause in Public Education, 71 Colum. L. Rev. 1355 (1971), and authorities cited therein.

4 See generally U.S. Comm'N on Civil Rights, Federal Enforcement of Sahool DEsEGREgation 12-25 (1969); Bickel, The Decade of School Desegregation: Progress and Prospects, 64 Colum. L. REv. 193 (1964); Kaplan, Segregation Litigation and the SchoolsPart I: The New Rochelle Experience, 58 Nw. U.L. REv. 1 (1963).

5402 U.S. 1 (1971).

* See generally Fiss, The Charlotte-Mecklenburg Case-Its Significance for Northern School Desegregation, 38 U. CHr. L. REv. 697 (1971). 
The continued inability or unwillingness ${ }^{7}$ of the Supreme Court to give a comprehensive interpretation of the government responsibility question has had significant repercussions. Absent a finding that the government was somehow responsible for the segregation, a court has no jurisdiction under the equal protection clause of the fourteenth amendment. The continuing absence of a standard for determining whether government responsibility exists has, consequently, resulted in uneven enforcement patterns between North and South and among school districts within those regions. This disparate treatment has created the impression of arbitrariness ${ }^{8}$ and has undermined the credibility of a process that has never enjoyed widespread public support. ${ }^{9}$ In addition, lower courts, faced with the uncertainties of the government responsibility question, have frequently directed their attention to the causes of segregation rather than to the only relevant subject of inquiry-whether the costs of achieving desegregation in any given situation outweigh the legal, moral, and educational considerations favoring it.

This comment will study the recent attempts by courts to deal with the question of government responsibility and will suggest a standard that would provide a consistent and workable approach to the problem. Section I discusses general theories of government responsibility in the school desegregation context. Section II analyzes the continued absence of a standard for government responsibility by examining lower court decisions after Swann with respect to three overlapping aspects of the problem: (1) neighborhood schools, (2) school district lines, and (3) dismantling of formerly dual systems. Finally, section III suggests

7 The Supreme Court has denied certiorari numerous times in school desegregation cases that squarely raise questions of government responsibility. E.g., Davis v. School Dist., 443 F.2d 573 (6th Cir.), cert. denied, 404 U.S. 913 (1971); Downs v. Board of Educ., 336 F.2d 988 (10th Cir. 1964), cert. denied, 380 U.S. 914 (1965); Taylor v. Board of Educ., 294 F.2d 36 (2d Cir.), cert. denied, 368 U.S. 940 (1961). But see Keyes v. School Dist. No. 1, 445 F.2d 990 (10th Cir. 1971), cert. granted, 92 S. Ct. 707 (1972).

8 See Georgia v. Mitchell, 450 F.2d 1317, 1321 (D.C. Cir. 1971). A suit brought by the State of Georgia alleging uneven enforcement of desegregation laws between North and South was dismissed by the court on grounds that enforcement was within the domain of prosecutorial discretion and that segregation in the North was not the product of state action. See also Fiss, supra note 6, at 705.

9 In the 1972 Florida Primary Election, seventy-four percent of the voters favored a constitutional amendment against court-ordered busing. N.Y. Times, Mar. 16, 1972, at 1 , col. I (city ed.). Recent Harris Polls indicate that sixty-one percent of the nation feel that dual systems are "wrong" and that only eighteen percent consider them "right." When de facto segregation is substituted for dual systems, however, the figures are sixty percent "right" and nineteen percent "wrong." The Harris SuRvey Yearbook of Public OpInion 1970, at 225-26 (1971). A March, 1970 Gallup Poll found that forty-six percent of the nation believed that racial integration had been carried out "too fast" and that only seventeen percent thought "not fast enough." Gallup Poll Press Release, Mar. 12, 1970. 
an appropriate standard for determining whether government responsibility exists and, consequently, whether a school system meets the requirements of the fourteenth amendment.

\section{General Theories of Government Responsibility for Racial Imbalance in Public Schools}

The framework within which the problem of government responsibility arises may be briefly described. An equal protection claim is made by a black child attending a racially imbalanced public school. A racially imbalanced school may be defined as a school attended predominantly by blacks ${ }^{10}$ that has a significantly larger ratio of black to white students than other schools in the same district or geographic area. An imbalanced school is the semantic equivalent of a segregated school. A racially imbalanced school district may be defined as a district containing one or more imbalanced schools. A finding of a denial of equal protection can be derived from the holding in Brown I that segregated education is inherently inferior.

Racial imbalance alone is not, however, a denial of equal protection. The fourteenth amendment further requires government responsibility for the segregation. The theories of government responsibility that have been developed by courts dealing with this requirement have arisen in four contexts: (1) segregation arising from the maintenance of a dual system or vestiges thereof; (2) segregation arising from intentionally discriminatory governmental acts other than the maintenance of a dual system; (3) segregation arising from governmental acts, the probable effects of which were foreseeable; and (4) segregation not arising from governmental acts, but which could be remedied by positive governmental action.

Government responsibility is established most clearly in the first context, in which the district maintains a dual system-a system in which, by statute or practice, students are assigned to schools explicitly on the basis of race, resulting in one set of schools designated as white and one set as black. ${ }^{11}$ Since such systems were declared unconstitu-

10 It is difficult to give a precise numerical figure for determining when "imbalance" exists. Experience shows that when the percentage of blacks in a school surpasses a certain level, there is a significant probability that the remaining whites will flee the school. The Department of Health, Education and Welfare has estimated this "tipping point" at around forty percent. United States v. Board of School Comm'rs, 332 F. Supp. 655, 676-77 (S.D. Ind. 1971). See also Ditkoff, State Remedies for Racial Imbalance: Increasing Their Educational Impact, 3 Colum. SURvey Human Rights L. 1, 27-30 (1971); Note, Demise of the Neighborhood School Plan, 55 CORNEIx L. REv. 594,595 n.9 (1970).

11 The term "dual system" is often used to refer to a school system segregated through 
tional in Brown I, all formerly dual systems have made at least token changes in their methods of student assignment. The continued existence of imbalance in a formerly dual system can, however, be attributed to the failure of the state to dismantle completely the dual system, and the Supreme Court held in Swann that government responsibility persists as long as any "vestige" of the dual system remains.

The second context relates to racial imbalance caused by school board or other governmental acts, other than assignment of students explicitly on the basis of race, that are intended to create or maintain segregated schools. Included are such acts as gerrymandered attendance zones, racially motivated faculty assignment, school site location designed to foster imbalance, and various other practices intended to create or maintain an imbalanced system. Although the Supreme Court has never explicitly held that such actions, absent a formerly dual system, are sufficient to impose responsibility on the government for the segregation, lower courts have frequently done so.

The third context pertains to segregation created by such facially neutral school board acts as attendance zone designation or school site location that, although not intentionally discriminatory, have the natural and probable effect of creating or maintaining racial imbalance. Also included are such other governmental acts as enforcement of restrictive covenants and federal loan practices that have the foreseeable effect of fostering residential segregation and which may subsequently result in racially imbalanced schools. ${ }^{12}$ The erection of school district lines may also have the natural and probable effect of increasing imbalance where segregated residential patterns exist. Lower courts have often found government responsibility in these practices by inferring segregative intent from their foreseeable effects.

The fourth context encompasses what could be termed a per se approach. Government responsibility may be based on the premise that racially imbalanced schools are inherently unequal and that the failure of the school board or government to remedy this unequal treatment is a denial of equal protection regardless of the underlying causes. On this reasoning, the intent of the conduct and the foreseeability of the effect are irrelevant. A small but increasing number of lower courts have taken this approach.

any form of state action. It is used here to refer only to school systems that assign students explicitly on the basis of race.

12 The numerous methods of governmental encouragement of residential segregation have been well documented. E.g., Hearings on Emergency School Aid Act of 1970 Before the Subcomm. on-Education of the Senate Comm. on Labor and Public Welfare, 91st Cong., 2d Sess. 352-54 (1970). See also Note, supra note 10, at 605 n.53 and authorities cited therein. 
The four contexts tend to overlap, and the categorization is reflective more of the approaches taken by different courts than of actual differences in the underlying causes. Obviously, it is possible for more than one of these factors to contribute to racial imbalance in a given situation.

\section{Approaches to Government Responsibility After Swann}

The attempt by the Supreme Court to deal with the government responsibility question in Swann has engendered increased confusion in the lower courts as to how the question should be resolved. ${ }^{13}$ In Swann, the Court was confronted by a school board that had made no real effort to dismantle its formerly dual system, and this alone was clearly sufficient to support a finding of government responsibility. But Chief Justice Burger also pointed to numerous acts by the board, distinct from explicit assignment by race, that had been intended to perpetuate the segregation. The Court held that these acts, which included school site location, attendance zone designation, and faculty assignment, should be considered in determining whether the segregation was "state-imposed."14 The Court left unanswered whether and in what circumstances these activities alone would suffice to attribute responsibility to the government. Subsequently, lower courts have given divergent answers to these questions and have been able to find support in the broad, ambiguous language of Swann for almost any position taken. ${ }^{15}$

\section{A. Neighborhood Schools}

In a neighborhood school system, assignment is made on the basis of geographic proximity, with each student generally assigned to the school nearest his home. The courts are currently divided on the question whether use of this facially neutral criterion absolves the government of responsibility for racial imbalance in the school system. ${ }^{16}$

13 Prior to the decision, there had been some speculation that the Court would use Swann as a vehicle for clarifying many of the persistent problems. The Supreme Court, 1970 Term, 85 HARv. L. REv. 3, 75 n.9 (1971). See also Note, Swann v. Charlotte-Mecklenburg Board of Education: Roadblocks to the Implementation of Brown, 12 WM. \& MARY L. REv. 838 (1971); N.Y. Times, Sept. 1, 1970, at 21, col. 1.

14402 U.S. at 20-21.

15 Compare Soria v. Oxnaxd, 328 F. Supp. 155 (C.D. Cal. 1971), with Goss v. Board of Educ., 444 F.2d 632 (6th Cir. 1971). For commentary on how Swann affected the government responsibility question, see Fiss, supra note 6; Comment, The Permissibility and Necessity of Busing School Children to Attain Integrated Schools: Charlotte-Mecklenburg Board of Education-A Case Study, 20 KAN. L. REv. 165, 176 (1971).

16 Earlier cases that failed to find state action in an imbalanced neighborhood system include Deal v. Cincinnati Bd. of Educ., 369 F.2d 55 (6th Cir. 1966), cert. denied, 389 U.S. 847 (1967); Downs v. Board of Educ., 396 F.2d 988 (10th Cir. 1964), cert. denied, 380 U.S. 914 
The principal line of division centers on whether segregative intent is required and, if so, whether any elements in addition to the mere existence of imbalance are necessary to give rise to an inference of such an intent.

In Gomperts $v$. Chase, ${ }^{17}$ the plaintiffs challenged the school board's recission of a plan that would have achieved greater balance in the San Mateo, California school system. The district court required the plaintiffs to demonstrate that the state had been responsible for the imbalance. An assignment policy based on geographic proximity had created, among the six high schools in the district, one that was ninetyfour percent black. Although the board had never maintained a dual system, the plaintiffs alleged that the segregation was caused by other governmental acts, primarily official encouragement of residential segregation that had the natural and probable effect of creating imbalance. ${ }^{18}$ The court first stated that a denial of equal protection could be established if the imbalance had been "planned, encouraged, fostered, designed, or in some way created by law or by administrative action under the color of law."19 This did not, however, mean that the state was to be held responsible for the foreseeable effects of its acts. Rather, it meant that the state's policies must have been "motivated by purposeful desire to perpetuate and maintain racially segregated schools." 20 The court held that "the maintenance of racially imbalanced schools, as the product of neighborhood mix or otherwise," 21 did not indicate such a motivation. The court in effect granted an evidentiary presumption of regularity to the state and placed the burden on the plaintiffs to show intent. No presumption was created by the mere existence of imbalance.

In Bivins v. Bibb County Board of Education, ${ }^{22}$ the district court

(1965); Bell v. School City, 324 F.2d 209 (7th Cir. 1963), cert. denied, 377 U.S. 924 (1964). Contra, Taylor v. Board of Educ., 294 F.2d 36 (2d Cir.), cert. denied, 368 U.S. 940 (1961); United States v. School Dist. 151, 301 F. Supp. 201 (N.D. IIl. 1969).

17329 F. Supp. 1192 (N.D. Cal.), injunction pending appeal denied, 404 U.S. 1237 (Douglas, Circuit Justice, 1971).

18 In his denial of a stay pending appeal, Justice Douglas outlined the following alleged sources of government responsibility:

(1) California's Bayshore Freeway effectively isolated the Blacks and resulted in a separate and predominantly Black high school. (2) State planning groups fashioned and built the Black community around that school. (3) Realtors-licensed by the State-kept "White property" White and "Black property" Black. (4) Banks chartered by the State shaped the policies that handicapped Blacks in financing homes other than in Black ghettoes. (5) Residential segregation, fostered by state enforced restrictive covenants, resulted in segregated schools.

404 U.S. at 1239.

19329 F. Supp. at 1195.

$20 \mathrm{Id}$. at 1196.

$21 \mathrm{Id}$. at 1195.

22331 F. Supp. 9 (M.D. Ga. 1971), rev'd, No. 71-2983 (5th Cir., May 3, 1972). 
confronted a formerly dual system in which segregation had persisted after the adoption of a neighborhood system. The court held that the state could not be held responsible for residential patterns since they were the result of volitional decisions of private individuals. It refused to consider whether past school board or other governmental acts had been a factor in the residential segregation or whether the neighborhood system could have been arranged so as to decrease imbalance. Again, the use of a neutral assignment policy resulted in a strong presumption of regularity.

While still requiring motive, an increasing number of courts have been willing to infer intent from the foreseeability of effects of facially neutral acts. ${ }^{23}$ In Bradley v. Milliken, ${ }^{24}$ involving the Detroit school system, the district court found government responsibility primarily in various facially neutral school board and other governmental acts that had the "natural, probable and foreseeable" effect of keeping the schools segregated. Among these acts were Federal Housing Administration and Veterans Administration loan policies that encouraged "racially and economically harmonious neighborhoods"; judical enforcement of racially restrictive covenants prior to their prohibition by the Supreme Court in 1948; and such school board acts as altered attendance zones, transfer programs that allowed whites to escape from identifiably black neighborhood schools, and busing programs that operated to move only black students out of geographically closer overcrowded white schools into predominantly black schools with available space.

Similarly, in Davis v. School District, ${ }^{25}$ the Sixth Circuit found that several acts of the Pontiac, Michigan school board, including school site location, attendance zone designation, and faculty assignment, had had the effect of perpetuating imbalance caused primarily by residential patterns. Although there was no proof of explicit segregative intent, the court found that the acts, "taken together, ... support the conclusion that a purposeful pattern of racial discrimination existed in the Pontiac School System."26 The court relied on the broad language of Swann to

23 Numerous commentators have argued that segregative intent can invariably be found in the operation of a so-called de facto imbalanced neighborhood plan. E.g., Fiss, Racial Imbalance in the Public Schools: The Constitutional Concepts, 78 HARv. L. REv. 564, 584 (1965): "[T]n every case of racially imbalanced schools sufficient responsibility can be ascribed to government to satisfy the requirement that stems from the equal protection clause's proscription of unequal treatment by government." See also Carter, De Facto School Segregation: An Examination of the Legal and Constitutional Questions Presented, 16 W. REs. L. REv. 502 (1965); Comment, Constitutionality of Adventitious Segregation in the Public Schools, 1967 U. Irr. L.F. 680.

24338 F. Supp. 582 (E.D. Mich. 1971).

25443 F.2d 573 (6th Cir.), cert. denied, 404 U.S. 913 (1971).

$28 \mathrm{Id}$. at 576. 
support its finding of government responsibility although, as in Bradley v. Milliken, there was no history of a dual system. In both Bradley and Davis, the existence of imbalance acted to lighten the plaintiffs' burden of proving intent.

The confusion engendered by these diverse standards of government responsibility was again demonstrated in Keyes $v$. School District No. 1,27 in which imbalance within the Denver school system was held to be de jure in one part of the city and de facto in another, although the same school board administered both areas. The Tenth Circuit affirmed the district court finding ${ }^{28}$ that the northeast section of the city had been segregated by several acts of the school board-gerrymandering attendance zones, placing mobile classrooms in black areas, and locating new schools in the center of the black community. Although no overt intent was found, the court inferred impermissible purpose from the absence of sufficient justification by the board for its acts. ${ }^{29}$ As to the core area of the city, the court upheld the district court finding that the school board acts had not caused the severe imbalance despite the previous finding that the board had intentionally segregated the northeast section of the city. ${ }^{30}$

The result reached by the court in Keyes seems anomalous. It is rather improbable that the school board acts could have been wholly neutral in one part of the city and intentionally segregative in another. Moreover, previous cases always treated the school district as a unit; a finding that the state was responsible for imbalance in any of the schools usually has systemwide implications. ${ }^{31}$

27445 F.2d 990 (10th Cir. 1971), cert. granted, 92 S. Ct. 707 (1972).

28313 F. Supp. 61, 65 (D. Colo. 1970).

29 The Tenth Gircuit did not rule on the additional district court finding that the school board's recission of a plan that would have decreased the imbalance in the northeast section was in itself a sufficient basis for finding state action. $445 \mathrm{~F} .2 \mathrm{~d}$ at 1002. Cases that have found racially motivated state elimination of a benign racial objective to be violative of the fourteenth amendment include Reitman v. Mulkey, 387 U.S. 369 (1967); and Lee v. Nyquist, 318 F. Supp. 710 (W.D.N.Y. 1970), aff'd, 402 U.S. 935 (1971). See also Hunter v. Erickson, 393 U.S. 385 (1969). See generally Karst \& Horowitz, Reitman v. Mulkey: $A$ Telophase of Substantive Equal Protection, 1967 SUP. CT. REv. 39; Comment, James v. Valtierra: Housing Discrimination by Referendum?, 39 U. CHI. L. REv. 115 (1971).

30 In addition, the court of appeals reversed the district court determination that the existence of inferior conditions in the black schools was in itself a violation of equal protection. It reasoned that since it had not been shown that the school board had intentionally created the imbalance, the board could not be held responsible for the conditions resulting from the imbalance. 495 F.2d at 1004-05. Contra, Hobson v. Hansen, 327 F. Supp. 844 (D.D.C. 1971); cases cited note 40 infra.

31 E.g., Kelly v. Guinn, 456 F.2d 100 (9th Cir. 1972); United States v. School Dist. 151, 404 F.2d 1125 (7th Cir. 1968). But see United States v. Midland Independent School Dist., 334 F. Supp. 147 (W.D. Tex. 1971). See generally Cisneros v. Corpus Christi Independent 
The inference of intent from foreseeable acts was carried quite far in Kelly v. Guinn, ${ }^{32}$ a recent Ninth Gircuit decision. Despite genuine attempts by the school board to integrate the Las Vegas area schools, which had been balanced in 1954 and had since become segregated primarily through shifting residential patterns, Judge Browning based government responsibility on an inference of intent arising from four factors: (1) the existence of almost total segregation in the elementary schools of a racially mixed school district; (2) the pattern of faculty assignments, through which black teachers were assigned to predominantly black schools and white teachers to predominantly white schools, despite convincing educational justifications for the assignments proffered by the school board;33 (3) school construction policies that had the natural effect of aggravating imbalance; and (4) the board's decision to continue a "neighborhood" assignment policy at the elementary level while abandoning it at the secondary level in favor of a program designed to integrate the secondary schools. ${ }^{34}$

The court's authority for attribution of responsibility from the first three factors was Swann's discussion of intentional school board activities. The court's reading of Swann is especially significant since this case, unlike Swann, did not involve a previously dual system and in fact involved a system that by all indications had been making a conscientious attempt at integration. ${ }^{35}$ The inference of intent arising from the fourth factor, the board's failure to desegregate some of the schools,

School Dist., 448 F.2d 1392, 1395 (5th Gir. 1971) (Bell, J. dissenting) (treats question as unresolved); Fiss, supra note 6, at 705 .

32456 F.2d 100 (9th Cir. 1972).

33 The defendants argued that the faculty assignments were educationally justifiable because black students respond better to black teachers. Id. at 9 n.8. This argument was accepted by the Tenth Circuit in Keyes as a justification for the assignment of black teachers to the ghetto schools. 445 F.2d at 1007 .

34 In his request for congressional action on the moratorium on school busing that he proposed in March, 1972, President Nixon recommended that the legislation proscribe busing for kindergarten students and students in grades one through eight and that it allow busing as a last resort for students in grades nine through twelve. N.Y. Times, Mar. 18, 1972, at 1, col. 8 (city ed.). Compare The Supreme Court, 1970 Term, supra note 13, at 80:

[I] younger students are not to be bused, they will attend the most segregated schools. In terms of social and educational policy this may be a serious mistake. The critical stages in children's social and educational development are the earliest elementary school years, and if segregation does indeed do educational or social damage, early segregation may do harm that later integration cannot heal. [Footnotes omitted.]

35 Although busing was not used at the elementary level, the board did attempt to achieve greater balance in the elementary schools by establishing a "prestige" school in the black neighborhood with special programs and a low pupil-teacher ratio to which white students were encouraged to transfer voluntarily. Kelly v. Guinn, 456 F.2d 100 (9th Cir. 1972). 
approaches the theory that failure to reduce imbalance constitutes government responsibility regardless of the initial cause of the imbalance.

The theory that maintenance of an imbalanced neighborhood system is in itself a denial of equal protection ${ }^{36}$ was adopted in People $v$. San Diego Unified School District. ${ }^{37}$ The state trial court had dismissed a mandamus brought by the state attorney general demanding that the school board "take reasonably feasible steps to prevent, alleviate and eliminate racial imbalance" in the schools. The school system, in which assignment was based on the concededly neutral criterion of geographic proximity, apparently without gerrymandering or other racially motivated acts, nevertheless had substantial imbalance. The state court of appeals, reversing the trial court dismissal, found that the knowing failure of the board to remedy the imbalance, when it was shown to have resulted in inferior education for black students, was sufficient to attribute responsibility to the state. While recognizing that the presumption of educational inequality was rebuttable and that practical limits might make complete integration impossible, the court ultimately adopted an approach that would require a finding of government responsibility in most if not all cases of imbalanced schools. Under this approach, all evidentiary presumptions are shifted to favor the plaintiffs; the state is required to show either equality of education between white and black schools or the physical impossibility of desegregation.

The problem of attributing responsibility to the government for racial imbalance in the neighborhood school context continues to create different results. Consistency can be achieved only through a Supreme Court resolution of whether the mere creation or maintenance of an imbalanced system gives rise to a duty to desegregate, as it did in the San Diego case, or whether there must be a showing of segregative intent, as was required in Gomperts and Keyes. If the Court determines that intent must be shown, it must then decide whether and in what circumstances the foreseeability of the effects of school board acts should create a presumption of intent. The remoteness of the effects of many governmental acts makes this inquiry difficult. While gerrymandering of

36 Several commentators have advocated this approach. E.g., Sedler, School Segregation in the North and West: Legal Aspects, 7 Sr. Lours U.L.J. 228 (1963); Note, supra note 10. See also Fiss, supra note 6.

3719 Cal. App. 3d 252, 96 Cal. Rptr. 658 (4th Dist. Ct. App. 1971), cert. denied, 92 S. Ct. 1288 (1972); accord, Soria v. Oxnard, 328 F. Supp. 155 (C.D. Cal. 1971); Hobson v. Hansen, 327 F. Supp. 844 (D.D.C. 1971); Spangler v. Pasadena City Bd. of Educ., 311 F. Supp. 501 (S.D. Cal. 1970); Blocker v. Board of Educ., 226 F. Supp. 208 (E.D.N.Y. 1964); Branche v. Board of Educ., 204 F. Supp. 150 (E.D.N.Y. 1962). 
attendance zones into black or white areas can clearly be a direct cause of imbalance, other acts, such as enforcement of restrictive covenants prior to 1948 of state licensing or real estate brokers who discriminated in their selling practices, may affect attendance patterns only indirectly. As long as the identification of the cause of discrimination, with its many variables, remains a central judicial concern in the neighborhood school context, the possibility of formulating a consistent, workable standard will remain remote.

\section{B. School District Lines}

The geographic definition of a school district can have the effect, intended or otherwise, of creating racially imbalanced schools. For example, in a county predominantly white in the western part and predominantly black in the eastern part, a school district line dividing the county vertically can establish two racially imbalanced school districts. If it is assumed further that a district line drawn horizontally would result in integrated schools, the problem of responsibility for the segregation becomes apparent. ${ }^{38}$ If the district line has been drawn with the intention of furthering segregation, government responsibility is as clear as if the state had established a dual system. More difficult, however, is the situation in which the resulting segregation was not intended, but was foreseeable. Finally, there is the situation in which district lines, although neutral in purpose and nonsegregative in effect when drawn, have become a barrier to school integration as a result of shifting residential patterns, most commonly the white flight to the suburbs.

A second, closely related problem is whether school district lines may be transgressed in order to achieve integration. Clearly, if district lines are the result of segregative intent, a remedial plan could ignore the lines and restructure the districts in order to change their racial composition. District lines drawn independently of any racially motivated purpose present a more difficult question, to which courts have responded in a variety of ways.

In Spencer $v$. Kugler, ${ }^{39}$ a three-judge district court was faced with a challenge to a New Jersey statute establishing district lines coterminous with political boundaries. The undisputed effect of using this neutral criterion was to create severe imbalance among neighboring school districts in several parts of the state. The district court, finding the boundaries reasonable and drawn without racial motivation, dismissed

38 Compare Sedler, supra note 36 , at $252-54$, in which this example is used in the context of attendance zone boundaries rather than district lines.

39326 F. Supp. 1235 (D.N.J. 1971), aff d mem., 92 S. Ct. 707 (1972). 
the complaint on the ground that "the conditions complained of herein are precisely those considered by the Court in Swann to be 'de facto segregation', defined as racial imbalance that exists through no discriminatory action of state authorities." 40 The Supreme Court affirmed summarily over the dissent of Justice Douglas. ${ }^{41}$ Although the holding can be limited to situations in which district lines coincide with political boundaries, the clear implication is that district lines neutrally drawn are not unconstitutional. ${ }^{42}$

While the result in Spencer can be partly justified on the theory that the district lines did not create imbalance when first drawn, other cases have approved lines whose immediate effect was to increase imbalance. In a recent series of cases involving the separation of predominantly white districts from larger preexisting districts that had been predominantly black, ${ }^{43}$ the Fourth Circuit, sitting en banc, upheld the school board acts as nonsegregative in two of the three cases, even though the probable effect of the redistricting in all of the cases was to increase the imbalance. ${ }^{44}$ The majority held that the Constitution is violated only where segregation was the primary purpose for the modification of districts and found sufficient legitimate educational reasons ${ }^{45}$ to overcome any inference that discrimination had been the primary purpose. The majority and dissent disagreed primarily on the degree of scrutiny to which the board's acts should be subjected. In his dissent, Judge Sobeloff suggested that the justifications for acts having foreseeable segregative effects should be measured against a compelling

$40 I d$. at 1242.

41 In his dissent, Justice Douglas pointed to the many official decisions, such as those concerning FHA loan practices, public housing location, zoning, and enforcement of restrictive covenants, as examples of segregative governmental acts that render the concept of de facto segregation meaningless. By finding "a right to education in the environment of a multiracial community" equal to the right to vote, Justice Douglas used the reapportionment cases as precedent for his argument that redistricting was required. 92 S. Ct. at 707-10. See also note 57 infra.

42 The three-judge court decision was held res judicata in a later suit in the district court demanding simply that the state alleviate the imbalance. Spencer v. Kugler, 454 F.2d 839 (3d Cir. 1972).

43 Wright v. Council of City of Emporia, 442 F.2d 570 (4th Cir. 1971) (en banc), cert. granted, 404 U.S. 820 (1971); United States v. Scotland Neck Gity Bd. of Educ., 442 F.2d 575 (4th Cir. 1971) (en banc), cert. granted, 404 U.S. 821 (1971); Turner v. Littleton-Lake Gaston School Dist., 442 F.2d 584 (4th Cir. 1971) (en banc).

44 Only the Turner case upset the redistricting on the basis of a primary discriminatory motive. Cf. Haney v. County Bd. of Educ., 410 F.2d 920 (8th Cir. 1969); Burleson v. County Bd, of Election Comm'rs, 308 F. Supp. 352 (E.D. Ark.), aff'd, 432 F.2d 1356 (8th Cir. 1970).

45 The reasons put forward by the school board in the Scotland Neck case were a desire for more local control, a desire to raise property taxes in the new district in order to increase school expenditures, and a fear that white flight from the predominantly black countywide system would make integration impossible. 442 F.2d at 580-81. 
state interest standard, ${ }^{46}$ and he found that the board's justification fell far short of that standard. By placing the heavy burden of proving intent on the plaintiff, the Fourth Circuit in effect foreclosed the possibility of ever crossing the newly formed district lines to achieve greater balance among the districts.

A contrary approach was apparently taken by the Fifth Gircuit recently in Lee $v$. Macon County, ${ }^{47}$ which involved the secession of a city from a county school system, creating a separate school district that contained a larger proportion of whites than the county district. Rejecting the city's proffered educational justification, Judge Wisdom ordered the reconsolidation of the districts without the extended search for a dominant racial motive that the Fourth Circuit had required in an almost identical situation two months earlier. ${ }^{48} \mathrm{He}$ concluded that "the city cannot secede from the county where the effect-to say nothing of the purpose- of the secession has a substantial adverse effect on desegration of the county school district." 49

While Lee involved an obvious attempt to create new imbalanced school districts, ${ }^{50}$ the recent decision in Bradley v. School Board ${ }^{51}$ transgressed district lines to remedy preexisting imbalance. In ordering the consolidation of the predominantly black Richmond school district with two predominantly white suburban districts, Judge Merhige found literally every form of government responsibility to help justify his massive interdistrict integration order. ${ }^{52}$ With respect to the district

46 "If challenged state action has a racially discriminatory effect, it violates the equal protection clause unless a compelling and overriding legitimate state interest is demonstrated." Id. at 595. Judge Sobeloff criticized the majority's use of a primary purpose test as being too illusive and lenient.

47448 F.2d 746 (5th Cir. 1971), reaff'd, 455 F.2d 978 (5th Gir. 1972).

48 In fact, Judge Wisdom cited the two district court cases that were reversed by the Fourth Circuit in the Wright-Scotland Neck decisions as authority for his holding. 448 F.2d at 752 .

$49 \mathrm{Id}$.

50 The court in Lee explicitly stated: "It is unnecessary to decide whether longestablished and racially untainted boundaries may be disregarded in dismantling school segregation." Id.

51 Givil No. 3853 (E.D. Va., Jan. 5, 1972).

52 Aside from the existence of an undismantled dual system in Richmond, the court found both intentional and foreseeable school board acts with segregative effects. In addition, the court noted that "[i]f there is public education it must . . . be afforded to all on an equal basis," $i d$. at 87 , and since the court further held that integration was an essential element in securing equal education, a virtual per se approach was expounded.

Professor Fiss, referring to this kind of massive fault finding in a desegregation order that will obviously entail great costs, has said: "A court aware of these costs is likely to feel a need to justify its action in terms that have the quality of a moral imperative." Fiss, supra note 6, at 698. The Richmond case, with its massive interdistrict busing order, seems to be a perfect example of this phenomenon. In the Detroit case, Judge Roth concluded: 
lines, the court found three rationales for government responsibility: (1) the state had formerly operated a statewide dual system, of which the district lines were a vestige; ${ }^{53}$ (2) maintenance of the district lines had had the foreseeable effect of creating imbalance; ${ }^{54}$ and (3) the circumstances surrounding the use of the district lines, as well as their foreseeable effect, supported a finding of deliberate discrimination in the maintenance of the lines. ${ }^{55}$

By viewing the existence of the district lines as a continuing act even if the segregative effect was unintended and unforeseeable, the state may be held responsible for the imbalance and be required to cross district lines or to consolidate districts. This is essentially the approach taken by the Supreme Court in the reapportionment cases, ${ }^{56}$ in which the Court found a denial of equal protection in the continued existence of political district lines that had the effect of depriving individuals of an "equal" vote. ${ }^{57}$ Crossing district lines or consolidating districts can be further justified if equal educational opportunity is viewed as an obligation of the state and not just of the individual districts. Decisions invalidating the use of the local property tax to finance public education are based on this view. ${ }^{58}$ Applying this statewide

"In the most realistic sense, if fault or blame must be found it is that of the community as a whole, including, of course, the black components. . . . There is enough blame for everyone to share." Bradley v. Milliken, 338 F. Supp. 582, 592 (E.D. Mich. 1972).

53 Civil No: 3353, at 44-58; cf. Calhoun v. Cook, 322 F. Supp. 804, 809 (N.D. Ga. 1971), rev'd, No. 71-2622 (5th Gir., Oct. 21, 1971) (court of appeals remanded to the district court to study the possibility of consolidating the Atlanta school system with a surburban system). See also Harrington v. Colquit City Bd. of Educ., No. 71-2626 (5th Cir., Oct. 28, 1971); United States v. Board of School Comm'rs, 332 F. Supp. 655 (S.D. Ind. 1971); United States v. Texas, 321 F. Supp. 1043, 330 F. Supp. 235 (E.D. Tex. 1970), aff'd in part, modified in part, 447 F.2d 441 (5th Cir. 1971).

54 "School officials in Virginia cannot plead ignorance of the crucial role race plays in education. When their acts perpetuate segregation or by new devices create it anew, their legality will be gauged by their natural, probable, and foreseeable effect." Civil No. 3353 , at $62-63$.

$55 I d$, at 83 .

56 E.g., Reynolds v. Sims, 377 U.S. 533 (1964).

57 See Kurland, Equal Educational Opportunity: The Limits of Constitutional Jurisprudence Undefined, 35 U. CHI. L. REv. 583, 585-86 (1968). Cases using the reapportionment analogy to justify the crossing of district lines include Haney v. County Bd. of Educ., 410 F.2d 920, 925 (8th Cir. 1969); Bradley v. School Bd., Civil No. 3353, at 64 (E.D. Va., Jan. 5, 1972); and Jenkins v. Township of Morris School Dist., 58 N.J. 483, 500, 279 A.2d 619, 628 (1971). See also RAcial Isolation, supra note 2, at 259.

58 Van Dusartz v. Hatfield, 40 U.S.L.W. 2228 (D. Minn., Oct. 12, 1971); Rodriguez v. San Antonio Independent School Dist., 337 F. Supp. 280 (W.D. Tex. 1971); Serrano v. Priest, 5 Cal. 3d 584, 487 P.2d 1241, 96 Cal. Rptr. 601 (1971); Robinson v. Cahill, 287 A.2d 187 (N.J. Super. Ct. 1972). But see McInnis v. Shapiro, 293 F. Supp. 327 (N.D. Ill. 1968), aff d per curiam, 394 U.S. 322 (1969). See generally Coons, Clune, \& Sugarman, Pravate Wealth and Public Education 350-52 (1970); Shoettle, supra note 3. 
obligation of equality to the problem of imbalance would require a court to look beyond the district lines to determine the existence of and fashion a remedy for imbalance.

This approach was followed recently in Jenkins $v$. Township of Morris School District, ${ }^{59}$ in which the New Jersey Supreme Court held that even where segregation in the formation of districts has not been intentional, "governmental subdivisions of the state may readily be bridged when necessary to vindicate state constitutional rights and policies."60 While the decision was permissive rather than mandatory with respect to the district lines, the case provides additional support for holding segregative district lines to be per se denials of equal protection. ${ }^{61}$

\section{G. Formerly Dual Systems}

The question of the formerly dual system that has adopted a neutral assignment policy warrants separate examination since courts may apply a different standard to this situation than to one in which a dual system never existed. Courts may hold racial imbalance to be a per se violation of equal protection in the context of a dual system and apply a less strict rule in other contexts. Under such a per se rule, the former policy of assignment explicitly on the basis of race would be sufficient to attribute responsibility to the government for any continued imbalance.

The use of a per se rule is supported by Green $v$. New Kent County School Board, ${ }^{62}$ in which the Supreme Court held that a school board

5958 N.J. 483, 279 A.2d 619 (1971), noted in 3 SETON HALC L. REv. 259 (1971).

$60 \mathrm{Id}$. at $500,279 \mathrm{~A} .2 \mathrm{~d}$ at 629 .

61 The legal significance of state lines as impediments to integration was dealt with in Bullock v. Washington, No. 24,862 (D.C. Cir., Jan. 19, 1972), in which the court refused to strike down a congressional statute that removed funds from a program that had paid for the busing of black students from all-black District of Columbia schools into various white districts in Maryland that had voluntarily offered the program. Over a strong dissent by Judge Robinson, the court concluded that since the equal protection clause speaks in terms only of a state's denial of equal protection, there is no right to equal education beyond the borders of each state. The opinion implied that a court could never order the crossing of state lines to overcome imbalance and, in addition, sanctioned a legislative act that had the practical effect of making even a voluntary crossing impossible. Inasmuch as the District of Columbia schools are ninety-seven percent black, the decision precludes any possibility of their achieving integration. The court's statement that "the relevant unit of equality as it were, is, at least in the context of public education no larger than the state" and further that "relevant units, of course, may be smaller than state wide," $i d$. at $15 \& \mathrm{n} .28$, reflects the judicial uncertainty about this question. The dissent argued that the removal of funds was a legislative act that had the foreseeable effect of denying black children the means to integrate and should therefore be held an unconstitutional, racially motivated legislative act. Cf. Reitman v. Mulkey, 387 U.S. 369 (1967); Lee v. Nyquist, 318 F. Supp. 710 (W.D.N.Y. 1970), aff'd, 402 U.S. 935 (197I).

62391 U.S. 430 (1968). 
has an affirmative duty to dismantle a dual system and that the adoption of a freedom-of-choice plan that fails to eradicate imbalance does not satisfy this obligation. In Swann, the Court struck down an assignment plan based on geographic proximity where the effect was perpetuation of the imbalance of a formerly dual system. Since Swann involved a totally noncompliant school board that had continued to operate the system in a discriminatory fashion, it remains uncertain whether imbalance alone in the formerly dual system would have supported the decision.

At what point a dual system is sufficiently dismantled to become "unitary" remains a great mystery. ${ }^{63}$ The difficuties in making this determination were compounded by the ambiguous remarks of Chief Justice Burger at the end of the Swann opinion:

At some point, these school authorities and others like them should have achieved full compliance with this Court's decision in Brown I. The systems would then be "unitary" in the sense required by our decisions in Green and Alexander.

It does not follow that the communities served by such systems will remain demographically stable, for in a growing, mobile society, few will do so. Neither school authorities nor district courts are constitutionally required to make year-by-year adjustments of the racial composition of student bodies once the affirmative duty to desegregate has been accomplished and racial discrimination through official action is eliminated from the system. This does not mean that federal courts are without power to deal with future problems; but in the absence of a showing that either the school authorities or some other agency of the State has deliberately attempted to fix or alter demographic patterns to affect the racial composition of the schools, further intervention by a district court should not be necessary. ${ }^{64}$

Some courts, interpreting "compliance" to mean only that the overt vestiges of a dual system must be eradicated, have upheld neighborhood systems in which imbalance persists, ostensibly because of segregated residential patterns ${ }^{65}$ or white exodus from the school system. ${ }^{66}$ These

63 This question has been termed "the central riddle of the law of school desegregation." Fiss, supra note 6, at 697; see Craven, Integrating the Desegregation Vocabulary-Brown Rides North, Maybe, 73 W. VA. L. REv. 1 (1971); Comment, Busing, Swann v. CharlotteMecklenburg and the Future of Desegregation in the Fifth Circuit, 49 TEx. L. REv. 884, 886-95 (1971).

64402 U.S. at 31-32. It has been suggested that this passage of the Court's opinion may have been included as a compromise in order to insure a unanimous vote. Fiss, supra note 6 , at 703 n.Il.

65 E.g., Bivins v. Bibb County Bd. of Educ., 331 F. Supp. 9 (M.D. Ga. 1971).

66 E.g., Boyd v. Pointe Coupee Parish School Bd., 332 F. Supp. 994 (E.D. La. 1971). 
courts have distinguished Swann on the ground that it involved a totally noncompliant school board that had made no genuine effort to integrate. 67 Limiting Swann to a "bad man" theory permits perpetuation of imbalance in a formerly dual system simply by institution of a neutral neighborhood assignment policy.

Other courts have reached the same result by limiting the concept of "vestiges of a dual system" to exclude the mere persistence of racial imbalance. In Bivins $v$. Bibb County Board of Education, ${ }^{68}$ the plaintiff blacks applied to the district court for additional relief after the Swann decision. Despite the prior maintenance of a dual system and the continued imbalance, the court held the system to be unitary since the overtly racial criteria of the dual system had been eliminated. Giting the previously quoted passage from Swann as support, the court stated:

All racial barriers have been removed from the Bibb County School system and from every school in it. The schoolhouse doors are open to all, completely without discrimination. Housing patterns are not vestiges of state-imposed school segregation. Similar housing patterns exist throughout the nation in areas where school segregation is said to be de facto rather than de jure. . . . The demography of other sections of this nation teaches us that this imbalance would be here today in Bibb County if there never had been state-imposed segregation. ${ }^{69}$

Similarly, in Boyd v. Pointe Coupee Parish School Board, ${ }^{70}$ a motion for supplemental relief filed by the United States after Swann was denied by the district court. Under a previously ordered plan, "all students were assigned to schools on a racially non-discriminatory basis," and if the plan had been adhered to, there would have been substantial balance. Most of the white students, however, subsequently left the public schools to attend private schools, creating severe imbalance in the public system, which the court termed "resegregation." The court denied relief on the ground that the "re-establishment of colored schools ... has in no way been brought about by State action," but was "purely de facto in nature."71 The court failed to consider whether

67 E.g., Goss v. Board of Educ., 444 F.2d 632 (6th Cir. 1971) (prior finding of a unitary system held res judicata even though imbalance remained and many of the remedial devices ordered in Swann had not been tried); Northcross v. Board of Educ., 444 F.2d 1179 (6th Cir. 1971); United States v. Board of Educ., 331 F. Supp. 466 (N.D. Ga. 1971); Green v. School Bd., 330 F. Supp. 674 (W.D. Va. 1971), rev'd in part sub nom. Adams v. School Dist. No. 5, 444 F.2d 99 (4th Cir. 1971) (en banc); Trahan v. Lafayette Parish School Bd., 330 F. Supp. 450 (W.D. La. 1971).

68331 F. Supp. 9 (M.D. Ga. 1971), rev'd, No. 71-2983 (5th Gir., May 3, 1972).

$69 \mathrm{Id}$. at 14.

70332 F. Supp. 994 (E.D. La. 1971).

71 Id. at 994-95. 
the plan itself had caused the departure of the whites or whether a different plan could be attempted that would avoid this result. It might well be true that integration is impossible in Pointe Coupee Parish; however, it does seem questionable that the state was in no way responsible for the imbalance.

A contrary approach was taken by the district court in the second hearing after the Supreme Court's remand in the Charlotte-Mecklenburg litigation. ${ }^{72}$ The school board claimed that the resegregation that had occurred after an approved plan had been put into effect was de facto. Judge McMillan found that, despite the adoption of a plan of neutral assignment, "[r]acial discrimination through official action has not ended in this school system."73 The court imposed an obligation on the school board to prevent resegregation for an indefinite period of time. Similarly, in the Richmond case, Judge Merhige responded unfavorably to an assertion that the resegregation there was de facto since a formerly all-white school had become all-black after integration was attempted: "To say that such schools are 'resegregated' implies not unfairly the continued official involvement in the creation and maintenance of schools identified as intended for one race."74

The broad "all vestiges" language ${ }^{75}$ and comprehensive remedial order of the Supreme Court in Swann has been used as support for the proposition that any imbalance in a formerly dual system constitutes a prima facie showing that the dual system has not been dismantled. In Monroe $v$. Board of Commissioners, ${ }^{76}$ the Jackson, Tennessee school board had adopted a neighborhood plan and had been making "substantial progress" toward desegregation. Since the board had not, however, utilized many of the remedial devices recommended in Swann, the Sixth Circuit remanded the case to the district court to consider the possibility of using any or all of these devices to achieve maximum desegregation. ${ }^{77}$ This approach, whereby a school system is unable to claim that all vestiges are removed as long as further integration is possible, was approved by the Fifth Circuit in Dandridge $v$. Jefferson Parish School Board. ${ }^{78}$ The district court, admitting that the

72 Swann v. Charlotte-Mecklenburg Bd. of Educ., 334 F. Supp. 623 (W.D.N.C. 1971).

$73 I d$. at 629.

74 Bradley v. School Bd., Civil No. 3353, at 22 (E.D. Va., Jan. 5, 1972).

75 "The objective today remains to eliminate from the public schools all vestiges of state-imposed segregation." 402 U.S. at 15.

76453 F.2d 259 (6th Cir. 1972).

77 Cf. Adams v. School Dist. No. 5, 444 F.2d 99 (4th Cir. 1971) (en banc); Robinson v. Shelby County Bd. of Educ., 442 F.2d 255 (6th Gir. 1971); Mapp v. Board of Educ., 329 F. Supp. 1374 (E.D. Tenn. 1971); Mims v. Duval County School Bd., 329 F. Supp. 123 (M.D. Fla.), aff'd, 447 F.2d 1330 (5th Cir. 1971).

78332 F. Supp. 590 (E.D. La. 1971), aff'd, No. 71-2542 (5th Cir., Feb. 11, 1972). 
point of compliance "may not be easily discernible," held that the continued attendance of twenty-one percent of black students in severely imbalanced schools constituted a prima facie showing that the dual system had not been dismantled. ${ }^{79}$

An approach suggesting that a formerly dual system does not completely abandon its affirmative duty even after achieving a unitary system was taken by the Fifth Gircuit in Lemon v. Bossier Parish School Board. 80 The court refused to allow the school board to use achievement testing for placement purposes despite the admitted fact that a unitary system had been achieved. The court refused to find the achievement testing per se invalid, but rather held that a system that had been "unitary" for only one semester was not free of its duty to desegregate..$^{81}$

Two basic questions relating to the existence of government responsibility in a racially imbalanced, formerly dual system must be resolved. First, if "all vestiges" of the dual system must be removed, what constitutes a "vestige"? While the Green case held that adoption of a neutral assignment policy is not enough in itself to constitute dismantling of a dual system, dicta in Swann imply that a "unitary system" may contain some imbalance. ${ }^{82}$ Although it is questionable whether the affirmative duty to maintain a balanced system should ever be removed from a formerly dual system in which continuing imbalance can be avoided, Swann seems to have suggested that this might be possible.

Second, in what circumstances should other governmental acts that foster segregation be sufficient to attribute responsibility if racial imbalance continues in a formerly dual system? Swann's discussion of deliberate school board acts implicitly supports at least some inquiry into other types of segregative activity, ${ }^{83}$ and the Richmond case demon-

79 Cf. Boykins v. Fairfield Bd. of Educ., No. 71-3028 (5th Cir., Feb. 23, 1972) (continued existence of a one-race school in itself negates any claim that the dual system has been eliminated despite the fact that the system was integrated "on paper"). In Swann, the Supreme Court explicitly held that where one-race schools remain in a formerly dual system, the burden of showing that the racial composition is not the result of present or past discriminatory conduct is shifted to the school authorities. 402 U.S. at 26. This burden has been viewed as "a heavy one." Fiss, supra note 6, at 701 .

80444 F.2d 1400 (5th Cir. 1971).

81 Accord, Moses v. Washington Parish School Bd., 456 F.2d 1285 (5th Cir. 1972).

82 "The constitutional command to desegregate schools does not mean that every school in every community must always reflect the racial composition of the school system as a whole." 402 U.S. at 24 . See also Winston-Salem/Forsyth Bd. of Educ. v. Scott, 404 U.S. 1221, 1228-31 (Burger, Circuit Justice, 1971).

83 The Court specifically limited its holding to school board activities:

We do not reach in this case the question whether a showing that school segregation is a consequence of other types of state action, without any discriminatory action by the school authorities, is a constitutional violation requiring remedial action by a 
strates the breadth of the search made by some courts. Other cases, however, focus solely on whether the dual system has been dismantled and do not consider whether other school board or governmental acts have contributed to continuing imbalance. Certainly, it is anomalous to apply a very narrow standard of government responsibility in a formerly dual system while other courts are finding government responsibility in systems in which the initial cause of the imbalance was almost entirely fortuitous. Comparison of such cases as Boyd or Bivins with Kelley v. Guinn or Bradley v. Milliken illustrates this anomaly.

\section{Raclal Imbalance: Government Responsibility and THE Duty to Desegregate}

\section{A. A Uniform Theory of Government Responsibility}

Although the inability of the lower courts to achieve a consensus may in large measure be attributed to the predilections of individual judges, ${ }^{84}$ the adoption of a uniform, coherent standard of government responsibility by the Supreme Court is a necessary step toward achieving greater consistency. The standard proposed here avoids illusive questions of motive ${ }^{85}$ and causation and focuses on the ability of a school board to achieve greater integration without sacrificing other important values.

The appropriate standard should be that responsibility attaches, regardless of actual intent, where a school board fails to remedy avoidable racial imbalance. Since public school attendance is compulsory and the state has complete control over attendance zone designation, school site location, student assignment, and all other components of a school system, it seems proper to hold the state accountable for harm caused by the school system that the state might reasonably have prevented..$^{86}$

school desegregation decree. This case does not present that question and we therefore do not decide it.

402 U.S. at 23.

84 See U.S. Comm'n on Civil Rights, FEderal Enforcement of SGHOOL Desegregation 39-46 (1969). "A small minority of Federal Judges . . . have indicated by their past judicial actions that they will not, where school desegregation . . . cases are concerned, discharge their responsibilities impartially." Id. at 40. See also V. NAVASKY, KENNEDY JUSTICE 243-77 (1971); J. Peitason, FIfTy-eight Lonely MEN (1961); The Supreme Court, 1970 Term, supra note 13, at 81; Note, The Congress, the Court and Jury Selection: A Critique of The Civil Rights Bill of 1966, 52 VA. L. REv. 1069, 1087-89 (1966); Note, Judicial Behavior in the Fifth Circuit, 73 YALE L.J. 90, 93-95 (1963).

85 See Cohen, supra note 3, at 266; Ely, Legislative and Administrative Motivation in Constitutional Law, 79 YALE L.J. 1205, 1289-98 (1970).

86 Cf. Branche v. Board of Educ., 204 F. Supp. 150, 153 (E.D.N.Y. 1962): "The educational system that is thus compulsory and publicly afforded must deal with the inadequacy arising from adventitious segregation; it cannot accept and indurate segregation on the ground that it is not coerced or planned but accepted." See RAciac Isolation, supra note 2, at 245; Sedler, supra note 36. There is ample Supreme Court authority for an 
This rule has its analogue in the traditional tort principle that holds a man liable for harm done by an instrumentality under his control. No liability would attach, however, if the harm were unavoidable-that is, impossible or unduly costly to prevent. In Learned Hand's classic statement of the rule, the defendant would be liable unless the "burden of adequate precautions" exceeded the probability of injury that might occur multiplied by the gravity of that injury. ${ }^{87}$ Under such reasoning, the state should be absolved of responsibility for imbalance only where it can show that greater balance is impossible or that the cost of achieving it exceeds the risk of harm created by the imbalance.

In a determination of whether the costs of avoidance exceed the risk of the resulting wrong, in a case of racial discrimination under the fourteenth amendment, the applicable legal standard requires the state to show a "compelling state interest" in order to justify its conduct. ${ }^{88}$ This "new equal protection" test, while admittedly vague, provides a doctrinal framework within which the courts can gradually supply consistent content. In applying this standard in contexts other than school desegregation, courts have invariably found alternative, nondiscriminatory means of accomplishing the legitimate ends sought by the state. Consequently, a state has never succeeded in showing its interest to be

approach that disregards motive: "[N]o state may effectively abdicate its responsibilities by either ignoring them or by merely failing to discharge them whatever the motive may be. It is of no consolation to an individual denied the equal protection of the law that it was done in good faith." Burton v. Wilmington Parking Authority, 365 U.S. 715, 725 (1961). In a recent case, the Fifth Circuit, sitting en banc, held that where a town dispenses municipal services in a manner that deprives the black community of equal treatment, the fourteenth amendment is violated even though no discriminatory motive is shown:

In order to prevail in a case of this type it is not necessary to prove intent, motive or purpose to discriminate on the part of city officials. We feel that the law on this point is clear, for "equal protection of the laws means more than merely the absence of governmental action designed to discriminate; ... we now firmly recognize that the arbitrary quality of thoughtlessness can be as disastrous and unfair to private rights and to public interest as the perversity of a willful scheme."

Hawkins v. Town of Shaw, No. 29013, at 2 (5th Cir., Mar. 27, 1972) (en banc) (emphasis in original), aff'g 437 F.2d 1286 (5th Cir. 1971), citing Norwalk CORE v. Norwalk Redevelopment Agency, 395 F.2d 920, 931 (2d Cir. 1968).

87 United States v. Carroll Towing Co., 159 F.2d 169, 173 (2d Cir. 1947). The liability of a barge owner for damages caused by his escaped, unguarded barge was determined by Judge Hand's calculus of risk, in which legal responsibility is the function of three variables: (1) the probability of injury occurring (P), (2) the gravity of the injury if it does occur $(\mathrm{L})$, and (3) the burden of adequate precautions against it $(B)$. When $B>P \times L$, there is no liability.

88 E.g., Loving v. Virginia, 388 U.S. 1 (1967); McLaughlin v. Florida, 379 U.S. 184 (1964). See generally Developments in the Law-Equal Protection, 82 HARv. L. REv. 1065, 10871131 (1969). "This higher burden requires that a state show not only that its objective could not be attained by a measure which did not draw racial distinctions, but also that the public interest involved outweighs the detriments that will be incurred by the affected private parties." Id. at 1103 . 
compelling..$^{89}$ In the school context, however, while the burden on the state would be heavy, it would not be insurmountable since it is often impossible or extremely impracticable to construct a school system with. out racial imbalance.

If the compelling state interest standard were employed to determine government responsibility, the court's inquiry would be identical with that which should properly be made in formulating a remedy once government responsibility is established ${ }^{90}$ - whether a compelling state interest precludes greater balance. The following section suggests criteria to guide the court in answering this question.

\section{B. Balancing Under the Compelling State Interest Test: Counter- vailing Costs}

The essence of the desegregation suit is the quest for equal educational opportunity. If, however, the state demonstrated that the overall quality of edcuation would suffer if desegregation were attempted, then under the compelling state interest test, desegregation would be avoided. ${ }^{91}$ Moreover, other legitimate state interests are often affected by a massive integration order. In a determination of whether the compelling state interest burden was met, the following costs would be relevant.

\$9 E.g., McDonald v. Board of Election Comm'rs, 394 U.S. 802 (1969); Shapiro v. Thompson, 394 U.S. 618 (1969).

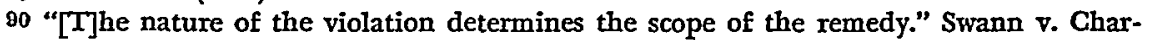
lotte-Mecklenburg Bd. of Educ., 402 U.S. 1, 16 (1971). Cf. Note, supra note 10, at 609: "The duty to ease racial imbalance in public schools and the appropriate relief a court might order are inseparable." See also Fiss, supra note 23, at 598.

91 Under the compelling state interest test, the decisions that seem correct for each of the various educational possibilities that would arise from any decision to integrate may be charted as follows. ( $D=$ decreased quality of education, $U=$ unchanged quality of education, $\mathrm{I}=$ increased quality of education, $\mathrm{N}=$ no integration, $\mathrm{Y}=$ integration.)

$\begin{array}{llllllllll}\text { Effect on white students } & \text { D } & \text { U } & \text { D } & \text { I } & \text { D } & \text { U } & \text { I } & \text { U } & \text { I } \\ \text { Effect on black students } & \text { D } & \text { D } & \text { U } & \text { D } & \text { I } & \text { U } & \text { U } & \text { I } & \text { I } \\ \text { Decision } & \text { N } & \text { N } & \text { N } & \text { N } & \text { ?* } & Y \dagger & \text { Y } & \text { Y } & \mathbf{Y}\end{array}$

- This is obviously the difficult category. Assuming that deprivations are the result largely of white discrimination, it does not seem inequitable to accept some compensatory redistribution in favor of blacks if absolutely necessary; however, there is obviously a limit to this that will be a question of fact in each case. Cf. United States v. Jefferson County Bd. of Educ., 372 F.2d 836, 900 (5th Cir. 1966); Hobson v. Hansen, 269 F. Supp. 401, 515 (D.D.C. 1967). Contra, Kurland, supra note 57, at 590-91: "It is highly doubtful in my mind that the elimination of excellence is an appropriate price to pay for the symbol of equality." See also Kaplan, Equal Justice in an Unequal World: Equality for the NegroThe Problem of Special Treatment, 61 Nw. U.L. REv. 363 (1966); McAuliffe, School De. segregation: The Problem of Compensatory Discrimination, 57 VA. L. REv. 65 (1971).

+ Where the actual quality of education would be unchanged after integration, the decision should be to integrate because of the positive social aspects, beyond the strictly educational effects, arising from integration. 
1. Transportation Costs. The cost of busing is the strongest and most frequently asserted countervailing interest. ${ }^{22}$ Although busing may be burdensome, the Supreme Court noted in Swann that approximately thirty-nine percent of all public school children took buses to school in 1969-70.93 Busing therefore should not be considered undesirable simply because the destination is an integrated school. Busing, the Court held, should be precluded when it would "either risk the health of the children or significantly impinge on the educational process."94 In Swann, the Court upheld a district court order requiring busing trips that had a one-way duration of thirty-five minutes. Challenges to the reasonableness of trips of shorter duration seem unlikely to succeed, barring extraordinary circumstances. ${ }^{95}$ Whether the Court will uphold longer trips remains uncertain. ${ }^{90}$ It is clear, however, that the Constitution should not be held to require any transportation plan that keeps children on a bus for a substantial part of the day, consumes significant portions of funds otherwise spendable directly on education, ${ }^{97}$ or involves a genuine element of danger to the safety of the child..$^{88}$

82 In response to the antibusing hysteria sweeping the country, President Nixon proposed in March, 1972 a moratorium on all court-ordered busing for the purposes of "racial balance." N.Y. Times, Mar. 18, 1972, at 14, col. I (city ed.). If proposed implementing legislation is enacted, the prospects for achieving integrated education will be diminished considerably, although the constitutionality of such legislation is questionable. $C f$. Lee v. Nyquist, 318 F. Supp. 710 (W.D.N.Y. 1970), aff'd, 402 U.S. 935 (1971). See also Hunter v. Erikson, 393 U.S. 385 (1969); Reitman v. Mulkey, 387 U.S. 369 (1967); United States v. Klein, 80 U.S. 128 (1872).

93402 U.S. at 29. Testifying before a Senate committee, HEW Sec. Elliot Richardson recently noted that the number of students bused has increased by only two percent in the last two years. N.Y. Times, Mar. 26, 1972, § 4, at 3, col. 3.

94402 U.S. at $30-31$.

95 Cf. Brewer v. School Board, Nos. 71-1900, 71-1901, at 4 (4th Cir., Mar. 7, 1972) (en banc) (average trip of thirty minutes upheld as "not substantially different" from Swann).

86 In Winston-Salem/Forsyth Bd. of Educ. v. Scott, 404 U.S. 1221, 1227 (1971), Chief Justice Burger, sitting as Circuit Justice, indicated that an average time of three hours daily would be a "patent violation of Swann."

97 In Brewer v. School Bd., Nos. 71-1900, 71-1901 (4th Cir., Mar. 7, 1972) (en banc), the court held that where a desegregation plan requires transportation, the school board is under an obligation to provide it. The required expenditure of $\$ 3.6$ million ( $\$ 3$ million for capital outlays) for transportation during the first year was held to be reasonable, using Swann as a standard. Id. at 8-10. Cf. Eaton v. New Hanover County Bd. of Educ., 330 F. Supp. 78, 79 (E.D.N.C. 1971), aff'd, No. 71-1890 (4th Cir., Apr. 26, 1972) (en banc) (cost of thirty-eight new buses held not unduly burdensome). See also Singleton v. Jackson Municipal Separate School Dist., 332 F. Supp. 984 (S.D. Miss. 1971) (state government enjoined from withholding funds needed for busing).

98 In Boykins v. Fairfield Bd. of Educ., No. 71-3028 (5th Cir., Feb. 23, 1972), the court ordered the pairing of two schools for integration purposes although it would require the moving of children across an intersection that had been the scene of 147 accidents during the previous year. Judge Wisdom dismissed the school board's fears by recommend- 
Existing busing practices in an area are another factor to be considered in determining the propriety of a busing order. ${ }^{99}$ A school board that has been using large-scale busing to transport students to segregated schools can hardly be heard to object to a similar amount of busing to transport students to integrated schools. In Swann, the Court found justification for the busing order in Charlotte in the school board's prior use of busing-with an average one-way trip of more than an hour-to maintain segregation. ${ }^{100}$ Similarly, in the Richmond case, Judge Merhige was able to identify numerous examples of massive busing over long distances and over district lines employed prior to his order for the purpose of keeping the schools separate. ${ }^{101}$

2. Elimination of Neighborhood Schools. Integration frequently results in the elimination of neighborhood schools. This change may be considered a cost of integration since it hampers extracurricular activities, parent-teacher associations, and walk-in schools and interferes with associational preferences among members of a residential community. Some of these factors can lower the quality of education. ${ }^{102}$

It would appear inequitable, however, to place great weight on the white community's desire to retain a neighborhood school when the existence of the white neighborhood can usually be traced to acts of

ing the installation of a variety of safety measures, such as traffic lights, an overpass, or crossing guards. See also Davis v. Board of School Comm'rs, 402 U.S. 33, 36-38 (1971).

99 Numerous post-Swann cases have used the amount of busing previously existing in a system as a factor in determining how much busing should be ordered to overcome imbalance. E.g., Winston-Salem/Forsyth Bd. of Educ. v. Scott, 404 U.S. 1221, 1225 (Burger, Circuit Justice, 1971); United States v. Watson Chapel School Dist. No. 24, 446 F.2d 933, 937 (8th Cir. 1971); Northcross v. Board of Educ., 444 F.2d 1179, 1182-83 (6th Cir. 1971); Davis v. Board of Educ., 328 F. Supp. 1197, 1203 (E.D. Ark. 1971).

In his proposed busing moratorium, President Nixon relegated busing to the status of a remedy of last resort. The proposal appears to acknowledge, however, that prior use of busing is a relevant consideration in formulating a desegregation plan:

[S] uch a plan could not require increased busing of students in the sixth grade or below. If a plan involved additional busing of older children, then: (a) It could not be ordered unless there was clear and convincing evidence that no other method would work; (b) in no case could it be ordered on other than a temporary basis; (c) it could not pose a risk to health or significantly impinge on the educational process; (d) the school district could be granted a stay until the order had been passed upon by the court of appeals.

118 Cong. REC. H2214 (daily ed. Mar. 20, 1972) (emphasis added).

100402 U.S. at 30.

101 No. 3353, at 15-16, 177-84 (E.D. Va., Jan. 5, 1972). "The Court finds that the transportation contemplated will in no event be for a longer distance or time than the maximum now utilized by the respective county defendants." $I d$. at 184. The maximum busing required in the Richmond opinion was one hour. Id. at 238. In Calhoun v. Cook, 332 F. Supp. 804, 808 (N.D. Ga. 1971), the court rejected busing of "forty minutes or more" in a system that had not previously transported students.

102 See Glazer, Is Busing Necessary?, Commentary, Mar., 1972, at 47-49. But see Carter, supra note 23, at 506-07. 
public and private discrimination. ${ }^{103}$ Moreover, judicial approval of neighborhood schools encourages residential segregation by those whites who wish to remain in the public schools, yet avoid integration. Since a significant component of the deprivation inherent in segregated schools is the stigmatization resulting from the white majority's imposition of the segregation, imbalance flowing in part from black associational desires renders interneighborhood integration less compelling, particularly if the schools in black neighborhoods are not significantly inferior. It is, however, often difficult to ascertain the true preference of a majority of the black community. ${ }^{104}$

3. Alteration of Existing School Districts. The school district is the primary unit for both financial and administrative control; integration requiring the alteration or elimination of existing districts can be a cost of considerable importance. Since the local property tax is gradually being eliminated as a basis for distributing educational funds, ${ }^{105}$ the argument for local fiscal control is decreasingly persuasive. If the concept of decentralized control is viable, on the other hand, existing school district lines should not be so readily disturbed.106 Particularly where districts coincide with preexisting municipal or county units, there are valid administrative reasons for their preservation. ${ }^{107}$ An opposite conclusion would follow, of course, where district

103 Compare Judge Merhige's response in Richmond: "[W]hile the assignment of pupils to neighborhood schools is undoubtedly both a sound and desirable concept, it cannot in this Circuit be approved if residence in a neighborhood is denied to Negro pupils solely on the ground of color, as this Court has found." Civil No. 3353, at 13 (E.D. Va., Jan. 5, 1972). See also note 12 supra.

104 In Norwalk CORE v. Norwalk Bd. of Educ., 298 F. Supp. 213 (D. Conn. 1969), aff'd, $423 \mathrm{~F} .2 \mathrm{~d} 121$ (2d Cir. 1970), a group of blacks unsuccessfully attempted to intervene in opposition to black plaintiffs' demands for integration, claiming that integration would destroy black neighborhood schools. The recent black political convention voted overwhelmingly against the use of forced busing to achieve integration. N.Y. Times, Mar. 13, 1972, at 38 , col. 4 (city ed.). Much of the black opposition to integration is grounded in the desire for black local control and should not be confused with the antibusing reasons generally proffered by the white community. Bell, Integration, a No Win Policy for Blacks?, IneQuality IN Education, Mar., 1972, at 39-40; Kirp, Community Control, Public Policy and the Limits of the Law, 68 MrGH. L. REv. 1355 (1970). See generally Diamond, Reform of the Government of Education: A Resolution of the Confict Between "Integration" and "Community Control", 16 WAYNe L. REv. 1005 (1971); The Supreme Court, 1970 Term, supra note 13 , at 79 n.30.

105 See note 58 supra.

108 The desire to retain local control was accepted as one of the justifications for avoiding greater integration in United States v. Scotland Neck City Bd. of Educ., 442 F.2d 575, 580 (4th Gir. 1971) (en banc), cert. granted, 404 U.S. 821 (1971). See generally THE CoMMUNITy School ConTroversy (A. Levin ed. 1969); Diamond, supra note 104.

107 Most other public services are dispensed through the local governmental unit, and the administrative burdens involved with creating a distinct unit for educational purposes can be significant. 
lines have been discriminatorily created or maintained.108

4. Potential for White Noncompliance. In any desegregation plan, the danger of subversion by white resistance is always present. As a general proposition, white recalcitrance must not be a factor in determining constitutional rights; ${ }^{109}$ the Supreme Court has made clear that white anger, unhappiness, or threats of violence should not be allowed to thwart the attainment of equal rights. ${ }^{110}$ If, however, the constitutional goal is integrated education, and as a practical matter white flight renders this goal unattainable, it cannot be ignored. ${ }^{111}$ Courts must continue to patrol against the many practices, ${ }^{112}$ such as subsidized private schools, that have been employed by whites to avoid desegregation, and white noncompliance must be discouraged by every means possible. Certainly, the result of a decision such as Keyes, ordering desegregation for one part of a city but not for another, can serve only to encourage noncompliant whites to move to a part of the city where their children can attend all-white schools free of judicial interference. The costs of white noncompliance are real, however, and must be dealt with by courts in determining whether further integration is attainable.

These are some of the more significant costs that must be considered by courts when determining whether a school board has demonstrated

108 President Nixon's busing moratorium proposal stated that "[s]chool district lines must not be ignored or altered [by the courts] unless they are clearly shown to have been drawn for the purposes of segregation." 118 Conc. REc. H2214 (daily ed. Mar. 20, 1972).

109 E.g., Watson v. Memphis, 373 U.S. 526, 536-37 (1963); Brewer v. School Bd., No. 171900, at 2-3 (4th Cir., Mar. 7, 1972) (en banc). But see Pittsburgh School Dist. v. Zebra, 287 A.2d 870 (Pa. Com. Ct. 1972) (preliminary injunction halting desegregation granted where white students were severely harrassed at a black school).

110 E.g., Cooper v. Aaron, 358 U.S. 1 (1958).

111 Cf. Yarborough v. Hulbert-West Memphis School Dist. No. 4, 329 F. Supp. 1059, 1064-67 (E.D. Ark. 1971), affd, No. 71-1524 (8th Cir., Mar. 27, 1972). The district court took note of the danger of whites fleeing if the "tipping point" was reached and therefore adopted a plan that would approach a seventy-thirty white-black ratio in all schools. "The problem here, however, is not the actual percentage figures in the plan so much as it is the workability, or prospects of success, of the plan." Id. at 1066 (emphasis in original). See also United States v. Scotland Neck City Bd. of Educ., 442 F.2d 575, 581 (4th Cir. 1971) (en banc), cert. granted, 404 U.S. 821 (1971) (fear of white flight as justification for not seeking maximum integration "entirely consistent with and may help implement the Brown principle"); Calhoun v. Cook, 332 F. Supp. 804, 805-06 (N.D. Ga. 1971); Davis v. Board of Educ., 328 F. Supp. 1197, 1201 (E.D. Ark. 1971). See generally A. BICKRt, ThE Supreme Court and the Idea of Progress 136-37 (1970).

112 E.g., Griffin v. County School Bd., 377 U.S. 218 (1964) (state tuition grants to segregated private schools); Wright v. City of Brighton, 441 F.2d 447 (5th Cir. 1971) (sale of public school to be used for segregated private school); Gilmore v. Montgomery, 337 F. Supp. 22 (M.D. Ala. 1972) (use of public parks and facilities by segregated private schools); Green v. Connelly, 330 F. Supp. 1150 (D.D.C. 1971), aff'd sub nom. Coit v. Green, 92 S. Ct. 564 (1971) (tax exemption for segregated private schools). 
a compelling state interest sufficient to justify the existence of racial imbalance. No formula has been devised by which these factors may be weighted. Unfortunately, the nature of the problem is not conducive to mathematical precision. Only by dealing explicitly with these factors can courts develop a line of precedents that will eventually allow trial courts consistently to identify a compelling state interest for racial imbalance. ${ }^{113}$ The development will very likely follow the rigorous standard established in Swann:

The remedy for such segregation may be administratively awkward, inconvenient, and even bizarre in some situations and may impose burdens on some; but all awkwardness and inconvenience cannot be avoided in the interim period when remedial adjustments are being made to eliminate the dual school systems. ${ }^{114}$

\section{Conclusion}

In the absence of Supreme Court guidance in defining a standard of government responsibility in the school desegregation context, courts have applied a broad array of legal tests. Although the fourteenth amendment should be applied consistently, the obligation to integrate schools has thus far been restricted to those areas where the courts have broadly construed the idea of government responsibility.

The deprivation resulting from school segregation is as real in a Northern city where the neglect or indifference of the state has allowed racial imbalance to occur as it is in a Southern city where it was once mandated by law. In one sense, an approach that requires a school board maintaining an imbalanced system to show a compelling interest to justify the imbalance merely restates a complicated problem in simple terms. In another sense, however, it provides a framework for a consistent development of legal criteria while allowing sufficient flexibility for courts to achieve reasonable results in individual cases.

Robert I. Richter

113 Cf. Comment, supra note 68. But see Note, Alternatives to Case-by-Case Attacks on School Desegregation, 16 How. L.J. 575 (1971).

114402 U.S. 1,28 (1971). 